\title{
The Question of Being: Greece, India and China
}

\author{
Antoaneta Nikolova \\ South-West University "Neofit Rilski", Blagoevgrad, BULGARIA \\ Faculty of Philosophy, Department of Philosophical and Political Sciences
}

Received: 19 December 2021 - Accepted: 24 December 2021 • Published Online: 27 December 2021

\begin{abstract}
One of the main features of the European perception of reality is that it is understood in terms of Parmenides' wondering that "there is Being". This concept is crucial for the Western tradition. In Western thought, the issue of Being is presented in pairs with two possible opposites: becoming and non-being. In this article, the concept of Being as it is presented in the Ancient Greek thought will be presented in comparison with similar concepts in Indian and Chinese traditions. The main aim of the paper is to outline the peculiarities and importance of each tradition.
\end{abstract}

Keywords: Greek version, Indian version, Chinese version.

\section{Introduction}

One of the main features of the European perception of reality is that it is understood in terms of Parmenides' wondering that "there is Being". Is this concept peculiar for the Western understanding? What is the place of the concept of "being" in Eastern traditions?

Some authors explicitly state that the problem of Being is "one which is never sensed or glimpsed in non-Western traditions" (Aubenque, 1991: 14, cit. in O’Leary, 2007: 173). Others like Halbfass, insist that "being is a universal concern, not a distinctively Western one" (see O'Leary, 2007: 170).

In Western thought, the question of being is connected with two possible opposites: becoming and non-being. Here, the main peculiarities of understanding of being and its opposites in Greek. Indian and Chinese thought will be discussed.

\section{The Greek version}

Parmenides gave the first explicit formulae of the concept of being. He described being as single, homogenous, boundless, eternal, unchangeable and immovable.

... what is, is uncreated and indestructible, alone, complete,

immovable and without end. Nor was it ever, nor will it be; for

now it is, all at once, a continuous one

(Parmenides, On Nature, VIII, English translation: John Burnet, 1892)

(C) Authors. Terms and conditions of Creative Commons Attribution 4.0 International (CC BY 4.0) apply. Correspondence: Antoaneta Nikolova, South-West University "Neofit Rilski", Faculty of Philosophy, Department of Philosophical and Political Sciences, Blagoevgrad, BULGARIA. E-mail: anikolova@swu.bg. 
The word which Parmenides used literally can be translated as "is-ness" or "the IS". This "is" is the totality of everything that exists. It is the eternal present that has neither past nor future. Nothing could be added to this is-ness, nothing could be removed from it.

Explaining the linguistic basis of its meaning Charles Khan distinguishes two characteristics (1978: 34-35):

"In Indo-European languages this "is" or "the verb "be" as copula... is characterised by two features which are essential for the philosophical development. The first I call the locative, the second the durative aspect. By the locative feature, I mean the fact that the verb serves for predication in general... but specifically for statements of place... for Greek common sense a thing cannot really be unless it is somewhere...

The second feature of the Indo-European copula, the durative aspect, is even more decisive for the Greek view of being. This is the aspect that contrast "be" with "become", eimi with gignomai as copula verb (and as with bhū in Sanskrit)... an opposition between stative and mutative, or static and kinetic. There is... an essential connection in Indo-European between the idea of being and idea of stability or remaining in the same state."

Although this is-ness is the only thing we have, it is not so easy to grasp it. Therefore, Parmenides splits our vision of reality into two paths: the path of the truth that is followed and achieved by contemplation, and the false path of opinion that is based on the invalid data of the senses. The path of the truth leads to the conclusion that there cannot be anything but being, the "is-ing". All visible plurality and changeability are but results of false opinion. They have no ontological validity:

... all these things are but the names which mortals

have given, believing them, to be true (Parmenides, On Nature, VIII, 35).

The vision of multiplicity and change is an illusion:

"To this One so many names will be assigned

as many are the things that mortals proposed, believing that they were true,

that they were born and perish, that they exist and do not exist,

that they changed the place and their bright colour" (8, 38-41)

From this splitting of the ways of knowledge follow some conclusions that are very important for Western thought. First, in terms of ontology, it gives ontological validity and importance only to that which is, to the being, and more or less leaves the issue of non-being out of the scope of philosophical consideration. Second, in terms of epistemology, it opposes two kinds of obtaining knowledge - via senses and via reasoning - preferring the latter one. Third, it combines both conclusions into an assertion that "is the same thing that can be thought and that can be" (Parmenides, III).

The identity between thought and being is essential for the accent that the consequent Western thought puts on the intelligible or rationally achievable aspect of reality.

In Eastern thought, we can also see a split between visible and true reality. The true reality, however, is neither rationally realised nor sensually perceived but is achievable through an "intuition" or "inner sense" that belongs neither to senses nor to rationality. Even though in the Parmenides poem, a goddess reveals the truth to the author while he is in a special state of inspiration, Parmenides insists on the importance of the reasoning.

Is, however, being an ideal, abstract or spiritual reality? 
"The historical background against which Parmenides did his thinking would tend to limit it to the corporeal and the real. The Ionian as well as the Pythagorean thought which Parmenides could be expected to have absorbed as he grew up could hardly have directed his attention to anything beyond the visible and extended world. It was that world that his predecessors had been striving to understand and explain. It is that world that Parmenides expressly endeavours to understand and explain in the final section of his poem. He offers, it is true, an unexpected and utterly original explanation of it. But nothing else in the entire poem seems indicated as the object of his study. In the setting in which Parmenides thought and wrote, anything other than the visible and tangible universe would seem incongruous as a subject for philosophising. In the composition of the poem, moreover, the poem envisages Parmenides as located in a world of change and highly differentiated objects, and using them as a means to rise to light. The starting point of the philosophical journey seems in this way to be represented as a world of plurality and change, a world already known in the opinions of mortals but now to be explained from the viewpoint of truth" (Owens, 1978: 20).

So, in this approach, there is no ontological split, only epistemological discrimination.

In Ancient Greek philosophy, the concept of being has two counterparts. One of them is "non-being". It is unthinkable and impossible. It is revealed as its negative opposite that has no ontological validity and meaning in itself and functions only in order to outline the characteristics of being.

The other counterpart is the concept of "becoming". According to Parmenides, change is mere appearance, an illusion. Heraclitus, however, considered it as the real nature of the world and presented the reality as all-embracing permanent transformation:

"Heraclitus says, you know, that all things move and nothing remains still, and he likens the universe to the current of a river, saying that you cannot step twice into the same stream" (Plato, Cratylus, 402 a).

"Those on the other hand, who say wooia would agree, well enough with Heraclitus that all things move and nothing remains still. So, they would say the cause and ruler of things was the

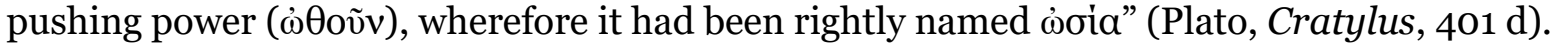

"I will tell you and it is not a bad description, either, that nothing is one and invariable, and you could not rightly ascribe any quality whatsoever to anything, but if you call it large it will also appear to be small, and light if you call it heavy, and everything else in the same way, since nothing whatever is one, either a particular thing or of a particular quality; but it is out of movement and motion and mixture with one another that all those things become which we wrongly say "are" - wrongly, because nothing ever is, but is always becoming" (Plato, Theaetetus, $152 \mathrm{~d})$.

“... the doctrine of Homer and Heraclitus and all their followers-that all things are in motion, like streams" (Plato, Theaetetus, $160 \mathrm{~d}$ ).

The concept of becoming has a linguistic foundation as well:

"In part, being was linguistically birthed. One of its progenitors was a peculiar characteristic of the ancient language known as Indo-European. This language sports a root word es- (in English, the verb "to be") that functions in a variety of ways, including as a verb of predication (e.g., "I am male"), location (e.g., "I am here") and existence ("I am"). That the root word es-, and with it, the Greek word einai, is already weighted in the direction of being is evident in the fact that the verb functions as a stative copula. This means that einai ("to be") can be conjugated in the durative tenses - the present and the imperfect - but not in the punctiliar or non-durative aorist tense. Thereby, it forms a linguistic contrast to the mutative copula ("to 
become") with its predisposition toward the alternative ontological idea of Becoming" (Grenz, 2005: 15-16).

Therefore, although being and becoming are nouns, they both derived from verbs, and they both carry the connotation of dynamism. One is the dynamism of the state, of the resting in itself stability. The other is the dynamism of the process, of moving changeability. Are they mutually exclusive? Western thought offers many examples of attempts to reconcile them, one of the most important belonging to Aristotle. Nevertheless, Western thought opposes being and becoming and being and non-being preferring being on the other part of the opposition.

\section{The Indian version}

In Ancient Indian thought there is a concept that usually is translated as "being". This concept could be found in one of the most important Vedic hymns, the Hymn of creation, which describes the most primordial state of the universe:

\section{नासदासीन नो सदासीत तदानीं नासीद}

nāsadāsīn no sadāsīt tadānīṃ nāsīd

This initial statement of pre-beginning has many translations:

"Then was not non-existent nor existent; Nor aught nor naught existed; The nonexistent was not, the existent was no; Then was not non-existent nor existent; Non-being then existed not nor being; Then even nothingness was not, nor existence; There was neither nonexistence nor existence then; The non-existent did not exist, nor did the existent exist at that time" (see Stenudd, 2014). "Neither what-is-not was nor what-is was then" or... "There was not what-isnot, and there was not what-is, then" (Pacitti, 1991).

The Sanskrit terms that are used here are sat and its negation, asat. Like the term "being" the term "sat" is a derivative form of the copula "to be". The ancient Greek

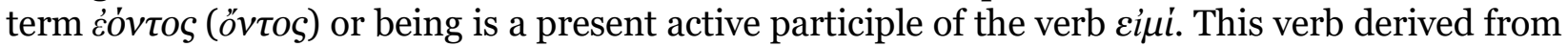
the proto-Indo-European verb esmi. The Sanskrit term sat is also a present active participle of the verb asmi that has the same roots.

There is, however, a clear difference between the concept of being and of the concept of sat. While in Parmenides's vision, the being is the one, that one that is the only existing, in Indian thought "sat" is an aspect of That one (Tad Ekam) that precedes both sat and its opposition asat. Terms of existence are not applicable to That one. In such a way, the Parmenides's one is simultaneously inclusive and exclusive. It includes everything that is and cannot include anything that is not, neither in the past, i.e., not yet existing, nor in the future not still existing. The opposition of "is" is impossible. It is the totality of everything, and there is nothing but it. Therefore, it is, it is unchangeable, and it is in the everlasting moment of the present. That one of the Indian thoughts also includes everything that will unfold from it, but this is an equal inclusion of both sat and asat. The predicate of existence and therefore, for time and space cannot be applied to that one. It precedes time and space, existence and non-existence:

There was neither existence nor non-existence then.

There was neither sky nor heaven beyond it.

What covered it and where? What sheltered?

Was there an abyss of water?

There was neither death nor immortality.

There was nothing telling night from day. 
The One breathed breathless autonomously.

There was nothing else.

There was darkness concealed in darkness.

All was water without shape.

The One enclosed in nothing

Emerged by the power of heat.

First to arise was desire,

The primal seed of mind.

Wise poets searching their hearts

Found the bond between existence and non-existence.

(Rig Veda, 10:129)

"The narrative begins "at that time" (tadnitm) when none of the divisions that characterize the world existed. What there was cannot be described as either asat "non-existent" nor as sat "existent". In many translations, asat and sat are taken as abstract nouns: "non-being" and "be-ing" or "non-existence" and "existence." But formally and firstly they are adjectival, and without any contrary signal in the text or the context, that is how the hymn's earliest audience would likely have understood them. Indeed, this is the interpretation of the oldest commentary on this hymn, SB 10.5.3.1: neva vd iddm dgre 'sad asln neva sad asit "In the beginning, this (world) was in no way non-existent, and it was in no way existent” (Brereton, 1999: 250).

That One (Tad Ekam), the One Reality (Ekam Sat) is the unnamed primordial source of everything. It is pre-beginning, but it is not some cosmological state that is overcome through the unfolding into plurality. As the Parmenides' being, it is the deepest and the most genuine essence of the Universe. In terms of later tradition developed on the base of Vedic hymns, it is equal to the state of turiya, unnamed oneness, the state of pure consciousness where subject and object, Brahman and Atman coincide.

In Hindu philosophy, That one has different names and interpretations. In a cosmic or objective sense, it is Brahman, the Ultimate Reality of the Universe. In the personal or subjective sense, it is Atman, the true inner self. As the Being of Parmenides, both Brahman and Atman are permanent, unchangeable, and true. Moreover, like the term Being although nouns they derived from verbs, and although they denote the unchanging reality, they have a connotation of dynamic. So, the term Brahman is a neuter noun deriving from the verb brh "to swell, expand, grow, and enlarge". The term Atman derived from the verb "etmen "breath" (a root found in Sanskrit and Germanic; source also of Old English æðm, Dutch adem, Old High German atum "breath,” Old English epian, Dutch ademen "to breathe"). ${ }^{1}$

Close to the term Brahman is the term Brahma. While however, Brahman is a metaphysical concept, a designation for the un-personified deepest essence of the Universe, Brahma is a name of a personified god, the first one in the Hindu trinity. According to Hinduism "The gods came later" with the unfolding of the world. The Hindu trinity denotes the three main states of every unfolding - beginning, duration and end. Brahma is connected with the beginning, the first stage of the unfolding.

What is the connection between the concept of Brahman and being? Brahman is a concept that "sums up the Hindu view of nature of ultimate reality" "Brahman is the cosmic principle of existence, the ultimate unifying and integrating principle of the universe" (Chaudhuri,

${ }^{1}$ https://www.etymonline.com/word/atman. 
1954: 47). As in Greek thought, it is also one, "That One", Tad Ekam, from the early Vedic hymns that is beyond time and space and even precedes gods. Brahman is "pure infinite being", but unlike the being in the Greek thought this is "not in the sense of an abstract concept common to different forms of existence but in the sense of the indeterminable creative source of all existence" (Ibid., 48-49). According to Upanishads, Brahman is permanent, lasting, invariable, and eternal. It is the unchangeable essence of everything. All these characteristics are close to the Eleatics vision of being as homogenous, eternal, unchangeable and immovable.

Brahman is defined as "sat": existing and true. Its affirmative denotation is "Sat-ChitAnanda”, i.e., it has characteristics of existence, consciousness and bliss. Its existence, however, is different from the existence of the world of change and multiplicity. Therefore, in Hinduism beside the term "sat" there is a term "bhava" which denotes the existence of the world of multiplicity and may be connected with the idea of becoming:

“... the term sat as used in Advaita Vedanta is a genuine verbal and conceptual equivalent of 'being'. The word itself is the present participle of the root as, to be. There is another root, $b h u$, with the same meaning, which also yields a variety of nouns and participles, none of which, however, can be translated Being with a capital B, as befits the need of ontology. Bhuta at most means a being; and bhava means becoming or coming to be or, even, the way something is" (Arapura, 1978: 111)

Another way to distinguish the different kinds of being is distinguishing of two kinds of Brahman. Saguna Brahman is the definable Brahman, Brahman with qualities that can be described. Namely, this kind of Brahman is defined as Sat-Chit-Ananda. This positive description, however, is interpreted as denoting the beginning of our approach to the Ultimate reality. When we go deeper, we realise that the being, consciousness and bliss of this Reality are of a different kind than the characteristics of the ordinary world. Therefore, Hinduism speaks about Nirguna Brahman, i.e., Brahman without qualities or rather, the undefinable Brahman. This means that Brahman could not be grasped within the words coined to describe the visible reality. This Nirguna Brahman is not not-existing. This double negation is of course affirmation but it is a complex affirmation, which implies that there are levels of sat, asat and their connections. In its essence, Brahman is "beyond the dualities of... existence and non-existence" (Chaudhuri, 1954: 47). Therefore, in the affirmative definition it is "satyasya satyam": "The Real of the Real", "The Truth of the Truth" while in the negative definition it is "not non-existing". These different forms of definition express two aspects of the One and of our approaches to it.

So, Hinduism has a notion of sat and asat that resembles the Greek notion of being and non-being. When the Ultimate reality is presented in its affirmative aspect for us it is denoted as "sat" and in this case the relation between sat and asat has much in common with the Parmenides assertion about being and non-being:

The unreal (asat) can never come into existence, and the real (sat) can never cease to be (Bhagavadgita, 2: 16, tr. Swami Tapasyananda)

In its essence, however, the Ultimate reality could not be described with either of these poles, it precedes all opposites.

It is challenging to outline a term describing the notion of "becoming" in this thought. There are terms, describing the transformation of That one into the multiplicity of visible world but these terms usually refer to illusion of manifestation and could not be applied for the suchness of reality as it is in Heraclites vision. 


\section{The Chinese version}

In Chinese thought there are also two concepts that usually are translated as being and non-being. These are $w u$, 無, and you, 有. As the Bulgarian Sinologist Teodora Koutzarova outlines, the philosophical category $w u$ means absence while the meaning of you is presence (Koutzarova, 2019: 63). Is it correct to translate them as "being" and "non-being"?

It is remarkable that in Western thought, the order gives the first place to the "being", presuming that it is the more important concept. In Chinese thought, the first place is given to $w u$, which is supposed to correspond to non-being. What are the differences between these pairs of concepts: being and non-being and wu and you?

(1) The concepts of being and non-being in Indo-European languages derived from the verb "to be" and are therefore connected with the issue of existence, while the Chinese terms $w u$, 無, and you, 有, mean "to have" or "to have not" and therefore "refer to the area of possessing not to the area of being” (Kobzev, 1994).

The verbs $w u$, 無, and you, 有, however, have an ontological implication as well, meaning both "to have" / "to have not" and "there is" / "there is not". In Chinese, there is a different couple of words meaning the positive and the negative aspects of the verb "to be". These are shih, 是, and $f e i$, 非. The same is the case in some Indo-European languages as well. In Bulgarian, for example, beside the verb "to be", there is another couple of verbs: "има" / "няма" that means both that something possesses/does not possess something or that there is/there is not something. Interesting is the case of the Russian language where the archaic form of the verb "to be" is currently used solely to denote possession. It is important to note that when such verbs are used with ontological meaning, they refer predominantly to the available being, to that which can be put within the frames of space and time. Usually, some spatial and/or temporal terms should be used to denote this kind of existence or non-existence:

Somewhere or sometime there is (was) something.

In such a way, the spatial and temporal limits are explicated.

Therefore, in their ontological aspect $w u$, 無, and you, 有, refer to that kind of existence which is available to the senses rather than to the mental abstractions.

(2) Being and non-being are nouns, although derived from verbs, while $w u$, 無, and you, 有, are predominantly verbs.

At least two conclusions follow from these differences. The first one is connected with the differences between the concrete and the abstract perceiving of existence. As Étienne Gilson puts it, "The relation of [the verb] "to be" to [the noun] "being" is not a reciprocal one. "Being" is conceivable, "to be" is not. We cannot possibly conceive an "is" except as belonging to something that is, or exists. But the reverse is not true. Being is quite conceivable apart from actual existence..." (Gilson, 1952: 2).

The second conclusion refers to the inherent connotation of verbs and nouns. In Greek and Latin languages, the nouns being and non-being were coined from the verb for existence "to be". This increasingly consolidates the understanding of reality as a stable and unchangeable entity while the Chinese terms $w u$, 無, and you, 有, emphasise the vision of its dynamic nature.

(3) The two pairs represent two different viewpoints, two different approaches to reality - from the position of the subject (in the case of being and non-being) and from the position of the object (in the case of $w u$, 無, and you, 有,). 
This difference can be revealed from the literal meaning of the sentences with the verbs $w u$, 無 and you, 有:

\section{天下有龍}

There are dragons in the world (literally: The world has dragons)

天下無龍

There are no dragons in the world (literally: The world has no dragons)

In such a way "in Chinese, one approaches existence from something outside... which has, in which there is, the thing in question." (Graham, 1959: 81). Western thought, from the other side, is "grounded in Greek and Latin" and "has generally approached the question from the opposite direction, from the thing which "is" or "exists" (Ibid.).

This different perspective - from the position of the object or from the position of the subject - is, in principle, a crucial difference between Far Eastern and Western thought. While the view point of Western thought is from the position of the observer, i.e., from within out, the Far Eastern perspective is inverted: from outward to inward.

This is obvious from the meaning of the verb "to see" in both systems of thought. While in Western languages, its connotation is that the observer, the subject, observes the object, in the Chinese language its meaning is rather that the object reveals itself, is shown to the observer. Regarding the problem of being "the object of you (有) is the subject of "is" (Graham, 1959: 81). This different perspective leads to different possibilities for rational conclusions. In one case, the role of the subject, of the observer and his/her thoughts and imagination is greater. This gives a possibility to separate the subject and the visible object and to enter the dimension of pure abstraction. In the other case, the role of the observed object is more significant, and it must be available for the senses. Therefore, "in Indo-European Languages a thing simply is, without implying anything outside it and it is the most abstract entities that the Platonic tradition most willingly credits with being. In Chinese, on the other hand, one approaches the thing from outside, from the world which "has" it, in which "there is" it. From this point of view, the more concrete a thing is, the more plainly the world has it" (Graham, 1959: 98).

Therefore, one of the differences between being and non-being, on the one side, and $w u$, 無, and you, 有, on the other side, is a difference between the more abstract and more concrete perception of reality.

The specifics of the concepts of $w u$, 無, and you, 有, in Chinese thought, can be revealed in the basic text of Daodejing. Already in the first chapter of the text, they appear with several corresponding pairs of concepts. These are:

$$
\begin{aligned}
& \text { absence - presence } \\
& \text { unnameable - nameable } \\
& \text { beginning - mother } \\
& \text { Universe (Heaven-Earth) - multiplicity } \\
& \text { secret (fine, subtle) - limit (limited) } \\
& \text { lack of aspirations - aspirations }
\end{aligned}
$$

It should be said that some of these pairs represent different interpretations of the same word combinations. This ambiguity of meanings is a distinctive feature of Daoist texts. In such a way, the "name" ceases to be a restrictive and fixed tool of the dual mind and approaches the requirement for the real naming - speaking beyond speaking. 
In these pairs $w u$ corresponds to the first components of the dyads: the absence, unnameable, beginning, subtle, and elusive, while you represents the second part: the presence, named, multiplicity, manifestation, thing-ness enclosed within restricted limits.

The French philosopher François Jullien defines $w u$ as "harmonising undifferentiation" and you as "differentiating actualisation" (Jullien, 2001). According to Chinese thought, the actualisation correlates with differentiation; transformation of potentiality into actuality means an increase of division and differentiation. The state of potentiality corresponds to undifferentiation. A distinctive feature of Chinese thought is that this state is perceived as harmonious. Therefore, Chaos here is not an opposition to the order but to the differentiation and separation. Chaos is not a dis-order but an undifferentiated state that has its own harmonious design. Another distinctive feature revealed in Jullien's translation is that both concepts present not static states, but processes. Thus, $w u$ presents the world in its aspect of undifferentiated fusion, of harmonious and self-harmonising unity, i.e., unity in becoming, in genesis. You represents the aspect of differentiation, division, and multiplicity within the process of actualisation.

The state of fusion and unity, especially in the Daoist thought, is regarded as more essential than that of division and multiplicity. Therefore, in some cases, $w u$ is considered as more primordial than you.

天下萬物生於有，有生於無

All things in the world are generated in presence; the presence is generated in absence. (Daodejing, 40)

For Daoists, absence or emptiness is very important because it allows the existence and functioning of things. It is so, however, when our approach is from the viewpoint of the differentiated things around us. When we try to understand the depth of the reality, none of the opposites precedes or surpasses the other just like it is in the Indian thought:

\section{此兩者，同出而異名}

These both arise simultaneously, but their names are different. (Daodejing, 1)

It is this non-duality where the opposites are not contradictory poles but complementary aspects of Oneness that reveals the innermost secret of the Daoist vision.

同謂之玄。玄之又玄，衆妙之門。

Togetherness is an innermost secret.

The innermost and the more innermost -

the door to the multiplicity of mysteries. (Daodejing, 1)

Therefore, neither $w u$ nor you, neither that which is elusive nor that which is fixed within borders have that deep primordial meaning that the concept of being has in Western thought. They and their union are only an approach, a door to the mysteries, still far from the true nature of the world.

We may also compare $w u$, 無, and you, 有, with the other pairs of opposites in the Greek thought, namely being and becoming. Neither $w u$, 無, nor you, 有, have the connotation of stable, unchanged self-sufficient unity that is associated with the idea of being. Both represent the reality in terms of change and are closer to the idea of becoming. As Ames and Hall correctly note „As a parody to Parmenides, who claimed that "only Being is”, we might say that for Daoist "only beings are", or taking one step further in underscoring the reality of the process of change itself, "only becomings are" (Ames \& Hall, 2003: 13-14). 


\section{Conclusion}

In all the three main philosophical traditions there are variants of the concept of being. While in the Greek tradition it is outlined as the most important concept that exclude its opposites, in the Indian and Chinese tradition this concept is usually regarded in an undistinguishable pair with its counterpart - nonbeing, and the Ultimate reality is presented as transcending all opposites including the ontological ones. The Greek and Indian concepts have similar linguistic roots while the Chinese ones are the most different. The roots of the Chinese version mirror the overall dynamic nature of Chinese thought, therefore the most important here is not the idea of being but the idea of becoming or - in terms of Chinese thought itself - of change and transformation.

This brief overview of the concepts of being in these different traditions shows that we should be very careful when translating concepts of different cultures that seems similar to our owns but in fact represent different vision of reality.

\section{Acknowledgements}

The research is a part of a project within Marie Sklodowska-Curie Action, European Union's Horizon 2020 Research and Innovation Programme, grant No. 753561.

The author declares no competing interests.

\section{References}

Ames, R. T., \& Hall, D. L., (2003). Daodejing, "Making this life significant”. New York: Ballantine Books.

Arapura, J. G. (1978). Some special characteristics of Sat (Being) in Advaita Vedanta. In Sprung Mervyn, (Ed.), The question of being east-west perspective. The Pennsylvania State University Press.

Brereton, J. P. (1999). Edifying puzzlement: Rgveda 10. 129 and the uses of enigma. Journal of the American Oriental Society, 119(2), 248-260

Chaudhuri, H. (1954). The concept of Brahman in Hindu philosophy. Philosophy East and West, 4(1), 4766.

Gilson, E. (1952). Being and some philosophers. Toronto: Pontifical Institute of Mediaeval Studies.

Graham, A. C. (1959). "Being” in Western philosophy compared with Shih/Fei and $\mathrm{Yu} / \mathrm{Wu}$ in Chinese philosophy - Asia Major. Vol. 7. N 1-2.

Grenz, S. J. (2005). The named God and the question of Being. A trinitarian Theo-ontology. Louisville, Kentucky, Westminster John Knox Press.

Jullien, Fr. (2001). The path to the goal: bypass or straight. [Жьолен, Фр., Путь к цели: в обход или напрямик. Москва. Россия]. Moscow. Russia.

Khan, Ch. N. (1978). Linguistic relativism and the Greek project of ontology. In Sprung Mervyn (Ed.), The question of Being East-West perspective (pp. 31-44). The Pennsylvania State University Press.

Kobzev, A. I. (1994). Ю - У "Presence / being” - "absence / nonexistence" - Chinese philosophy. [Кобзев, А. И. Ю-У"Наличие/бытие" - "отсутствие/небытие" - Китайская философия. Энциклопедический словарь. Москва. Россия]. Encyclopedic Dictionary. Moscow. Russia.

Koutzarova, T. L. (2019). Daodejing. A treatise on the way and the innate bestowal: A translation and a textological analysis. Sofia: East-West Publishing House. 
O'Leary, J. (2007). Heidegger and Indian Philosophy, in beyond orientalism. The work of Wilhelm Halhfass and its impact on Indian and cross-cultural studies, Eds. Eli Franco, Karin Preisendanz, Delhi.

Owens, J. (1978). Being in early Western tradition. In Mervyn Sprung (Ed.), The question of Being. EastWest perspectives, University Park and London: Pennsylvania State University Press.

Pacitti, D. (1991). Negation in Sanskrit: Rig Veda X, 129. http://www.pacitti.org/books 00199102.htm\#1. 
A. Nikolova - The Question of Being: Greece, India and China

C O A s 